\title{
On Semantic and Syntactic Structures of Sentences with Deadjectival Causative Verbs in Modern English
}

\author{
Robert Khachatryan \\ Yerevan State Linguistic University after V.Bryusov
}

B eing a universal notion, causation is expressed differently in different languages. Causation may be encoded in a range of linguistic structures, including word semantics, morphemes, prepositions, and periphrastic constructions (Comrie and Polinsky 1993; Dirven 1995; Shibatani 1976). The analysis of causative constructions essentially calls forth a synthesis of morphology, syntax, and semantics (Song 1996:1). The core of causative meaning is the cause-effect relationship that instigates a certain action or condition in another person or object. Dlugosh (1980:13) defines the causeeffect relationship as correlation between the cause and effect, in which the latter is not only a direct consequence of and generated by the former, but also its expression that causes a certain inducement.

As inferred from the title, this article investigates the semantic and syntactic structures of sentences formed with deadjectival causative verbs in Modern English. The analysis of these structures is carried out at two levels: the surface-syntactic level and the deep-semantic level. The semantic structure of the sentence is determined by the meaning of the deadjectival causative verb (the core of a structure) and a definite number of nominal members which semantically correlate with the core verb.

Causative verbs under investigation are derived from adjectives by morphological processes and retain semantic and formal correlation with the latter (Nedyalkov and Silnitsky 1969, 1973). The general word-forming meaning of these verbs is to confer someone or something with properties and qualities, expressed by the adjectival base. To this end, a causative verb embodies several new meanings, namely the categorial meaning of adjective, i.e. quality and property of an object, and the categorial meaning of word-forming formant "to confer, to become." Furthermore, certain lexical groups of deadjectival causative verbs are analyzed in order to reveal consistent patterns of relationship between the lexical meaning of the verb and its semantic and syntactic valences. The following semantic classes of deadjectival causative verbs are investigated in this article (Bogdanova 2000):

1. Causative verbs expressing changes in volume: to fill - to empty.

2. Causative verbs expressing changes in size: to shorten, to lessen, to deepen, to enlarge, and to widen.

The cause-effect relationship in causative constructions formed with the verbs under analysis entails syntactically obligatory valencies, namely the subject and the object. The analyzed data illustrate that the subject can be expressed by an animate noun $($ ex.1, 2) or by a pronoun, substituting a noun (ex.4, 5).

1) ....Mrs. Farnaby deliberately shortened the interview and silenced the lovers-still as resolute as ever to keep Amelius exposed to the adventurous freedom of a bachelor's life. (Collins, W. The Fallen Leaves) 
2) Miss Ingram placed herself at her leader's right hand; the other diviners filled the chairs on each side of him and her. (Bronte Ch. Jane Eyre)

3) I have soon known better in the cheerfulness and contentment that God has blessed me with and given me abundant reason for; and yet $\underline{I}$ have had to dry my eyes even then, when I have thought of my dear, brave, handsome, bright-eyed Charley, and the trust meant to cheer me with. (Dickens, Ch. The Cricket on the Hearth. A Fairy Tale of Home.)

4) "Good heavens!" I cried. "Who would associate crime with these dear old homesteads?" "They always fill me with a certain horror. It is my belief, Watson, founded upon my experience, that the lowest and vilest alleys in London do not present a more dreadful record of sin than does the smiling and beautiful countryside." "They always fill me with a certain horror". (Doyle, A. C. Selected Stories.)

The direct object can be expressed both by concrete (animate and inanimate) and abstract nouns depending on the semantics of the verb. For example, the direct object of verbs expressing changes in size and volume of an object is expressed by an inanimate concrete noun if the verb is used in its direct meaning (ex. 5, 6), and by an abstract noun if the verb is used in its figurative meaning (ex. 7, 8).

5) Down in the cellars, as up in the bed-chambers, old objects that he well remembered were changed by age and decay, but were still in their old places; even to empty beer-casks hoary with cobwebs, and empty wine-bottles with fur and fungus choking up their throats. (Dickens, Ch. Dombey and Son)

6) They ... suddenly widened their eves. (Fletcher J. The Paradise Mystery.)

7) I have spent an instructive afternoon in the rector's library, and have enlarged my knowledge by adding the fact that Vermissa is a flourishing little town at the head of one of the best-known coal and iron valleys in the United States. (Doyle, A. C. Selected Stories.)

8) I hope neither of us may ever have any cause to lessen our opinion of the other, Lucretia. (Dickens, Ch. Dombey and Son)

The majority of these verbs not only entail two obligatory syntactic valencies, i.e. the subject and object, but also retain optional valencies, which do not necessarily find their expression at the surface structure. The presence or absence of the third optional syntactic valency is determined by a range of factors, such as the semantics of the verb or the semantics of obligatory nominal elements. Thus, in the example below (ex.9) the absence of the third element water can be explained by the monosemanticity between the direct object and a possible prepositional object. 
9) He followed her into the little kitchen, where she filled a kettle and watched it come to the boil. (Dreiser Th. The Financier.)

Assumingly, the third element in this example can only be expressed by the noun water as teapot is usually filled with water. If it were filled with another substance, not specific to the given situation, its expression would be conveyed in the syntactic structure of a sentence as an optional element - a prepositional object.

10) Right after noon that day he filled the water buckets and went back to the little river for more. He filled his buckets with stones and sank them. (Defoe D. Robinson Crusoe.)

The same noun buckets is used in both sentences (ex.10). The first sentence illustrates that the expression of an optional element is not necessarily required; whereas, its omission implies that buckets were filled with water for what they are intended. In contrast, the second sentence illustrates that the expression of the optional element with stones is fully justified as it denotes an object, not specific to the given situation, and therefore, finds its expression in the syntactic structure of the sentence.

The expression of the optional element is obligatory if the direct object denotes an item which implies a range of possible optional elements. To this end, its expression at the surface structure is semantically justified, i.e. it explicitly reveals the semantics of the verb.

11) With perfect coolness Holmes slipped across to the safe, filled his two arms with bundles of letters, and poured them all into the fire. (Doyle, A. C. Selected Stories.)

12) Three smaller windows on the right-hand side filled the apartment with cold winter sunshine. (Doyle, A. C. Selected Stories.)

13) It cost me something in foolscap, and I had pretty nearly filled a shelf with my writings. (Doyle, A. C. Selected Stories.)

The objective of this article is twofold: to reveal an archetype of correlation between the lexical meaning of the verb and its semantic valencies and to compare the semantic structures of sentences formed with deadjectival causative verbs with the syntactic ones.

\section{Causative Verbs Expressing Changes in Volume (to fill - to empty)}

This subgroup comprises the antonymic pair of verbs to fill - to empty. The verb to fill means to make an object to become full. Conversely, the verb to empty means to discharge contents and denotes the emptiness of volume. Nevertheless, these antonymic verbs can be used in situations which entail the same members. Hence, the semantic structures of these verbs are presumably identical. The meanings of the verbs to fill and to empty entail at least two obligatory semantic valencies which correlate with the syntactic valencies differently. 
14) As I watched them Stapleton rose and left the room, while Sir Henry filled his glass again and leaned back in his chair, puffing at his cigar. (Doyle, A. C. Selected Stories.)

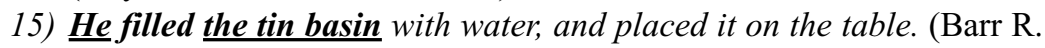
A Rock in the Baltic.)

16) The sudden termination of Colonel Brandon's visit at the park, with his steadiness in concealing its cause, filled the mind, and raised the wonder of Mrs. Jennings for two or three days ... (Austen J. Sense and Sensibility.)

The analysis reveals a choice of four semantic valencies: Agent expressing an animate instigator of the action, Patient expressing an animate bearer of the action, Objective expressing an inanimate bearer of the action, and Cause expressing force or object causing an action or state. The second obligatory element of the semantic structures with the verb to fill can express two basic meanings: Patient (ex.16) and Objective (ex.14, 15).

In tandem with a simple syntactic structure with two obligatory elements - the subject and the direct object, the verb to fill generates a complex semantic structure, which entails four obligatory semantic valencies: Agent, Cause, Patient, and Objective. Agent and Cause are in complementary distribution and do not concurrently occur at the surface level. Hence, both can only be expressed by the subject.

The verb to empty is less frequently used than the verb to fill as the former is mostly used in its figurative meaning. Conversely, the verb to empty denotes a certain physical action to make a particular object to become empty or hollow. The sentences formed with the verb to empty may represent the transformations of semantically simple sentences (ex. 17, 18, 19):

17) Mrs. Sowler emptied her glass, and looked hard at Jervy across the table. (Collins W. The Fallen Leaves.)

Mrs. Sowler caused her glass to become X.

Her glass became empty.

18) The Eldorado emptied its occupants into the street to see the test.

(London J. The Call of the Wild.)

The Eldorado caused its occupants to leave.

The Eldorado became empty.

19) For good measure they emptied the safe and turned it upside down.

(Miller H. Tropic of Capricorn.)

They caused the safe to become X.

The safe became empty.

The verb to empty generates similar situations and entails the same participants as its antonymic counterpart to fill does. The analysis illustrates that the verb to empty denotes a situation where the action is carried out by an animate participant in the semantic struc- 
ture, i.e. Agent. Thus, this semantic valency is expressed by the subject of a sentence. In this case, the syntactic and semantic structures of the sentences completely correspond to each other, and the subject corresponds to an animate participant of a causative situation.

20) What did you do after that? - Immediately after you emptied the cash drawer? (Miller H. Tropic of Capricorn.)

In rare cases, Patient and Objective can find their expression in an unusual syntactic position at the surface level.

21) One might almost have thought that when the man fell, she stood over him and emptied the contents of the revolver into him. (Doyle, A. C. Selected Stories.)

22) In any other case the conspirators would have simply called out their man, as they had many a time before, and emptied their pistols into his body ... (Doyle, A. C. Selected Stories.)

23) But the next instant Holmes had emptied five barrels of his revolver into the creature's flank. (Doyle, A. C. Selected Stories.)

Accordingly, the analysis indicates that the semantic structure with the verb to empty is simpler and different from that formed by the verb to fill. Almost all the examples indicate correspondence between sentence members and their semantic meanings.

\section{Causative Verbs Expressing Changes in Size \\ (to shorten, to lessen, to deepen, to enlarge, to widen)}

This subgroup comprises causative verbs which denote an event, causing internal changes in an object, namely increase or decrease in size. These verbs are mostly used in figurative meaning. However, the verb to enlarge in most cases is used in its direct meaning. The causing event may be either expressed by an animate noun which corresponds to Agent (ex. 24, 25), or by an inanimate concrete noun which corresponds to Cause (ex. 26).

24) Having now fixed my habitation, I found it absolutely necessary to provide a place to make a fire in, and fuel to burn: and what I did for that, and also how I enlarged my cave, and what conveniences I made, I shall give a full account of in its place ... (Defoe D. Robinson Crusoe.)

25) First, we rebuilt and enlarged the almshouses beyond all that Colonel John Mohune could ever think of, and so established them as to be a haven forever for all worn-out sailors of that coast. (Falkner J. Moonfleet.)

26) She wore horn-rimed glasses that enlarged her eyes and suggested the constant outrage to her soul of the sight she saw. (Steinbeck J. Pearl.) 
At the surface level, Patient and Objective correspond to the direct object and may be expressed by a concrete noun in its direct meaning (ex.27), or an abstract one in its figurative meaning (ex. 28, 29).

27) The momentary pleasure of success got the better of her; her eyes enlarged, and she involuntarily smiled in his face. (Hardy Th. Tess of the d'Urbervilles, A Pure Woman.)

28) I have spent an instructive afternoon in the rector's library, and have enlarged my knowledge by adding the fact that Vermissa is a flourishing little town at the head of one of the best-known coal and iron valleys in the United States. (Doyle, A. C. Selected Stories.)

29) During my confinement for want of clothes, and by an indisposition that held me some days longer, I much enlarged my dictionary; and when I went next to court, was able to understand many things the king spoke, and to return him some kind of answers. (Swift J. Gulliver 's Travels.)

The verb to shorten is the most frequently used verb in this subgroup. The action may be expressed both by Agent and Cause. More specifically, the analysis (ex. 30, 31, 32) does not indicate any interdependence between the direct and figurative meanings of this verb and its semantic valencies, expressed by the causing event.

30) Elizabeth had hoped that his resentment might shorten his visit, but his plan did not appear in the least affected by it. (Austen J. Pride and Prejudice.)

31) But if Regina happened to enter the room, or if Amelius contrived to find his way to her in some other part of the house, Mrs. Farnaby deliberately shortened the interview and silenced the lovers - still as resolute as ever to keep Amelius exposed to the adventurous freedom of a bachelor's life. (Collins W. The Fallen Leaves.)

32) Philip remembered the story of the Eastern King who, desiring to know the history of man, was brought by a sage five hundred volumes; busy with affairs of state, he bade him go and condense it; in twenty years the sage returned and his history now was in no more than fifty volumes, but the King, too old then to read so many ponderous tomes, bade him go and shorten it once more... (Maugham S. Of Human Bondage.)

As substantiated by the analysis, Patient (ex.33) and Objective (ex.34) may be expressed by an abstract noun.

33) With her constitution she should have lived to a good old age: her life was shortened by trouble". (Bronte Ch. Jane Eyre.) 
34) With all the sail I could make, I found I should not be able to come in their way, but that they would be gone by before I could make any signal to them: but after I had crowded to the utmost, and began to despair, they, it seems, saw by the help of their glasses that it was some European boat, which they supposed must belong to some ship that was lost; so they shortened sail to let me come up. (Defoe D. Robinson Crusoe.)

Thus, the analysis of the semantic structures with causative verbs to shorten, to lessen, to deepen, to enlarge, to widen reveals a pattern that these verbs are often used in figurative rather than literal meaning. The analysis further substantiates that the status of the syntactic structures is determined by their dependency on the semantic structures of the verb. More specifically, these verbs generate one syntactic structure with the subject and direct object and two semantic structures which differ from each other in how they express the causing event, i.e. whether the causing event is expressed by Agent or Cause.

On the basis of the analysis carried out, it can be concluded that deadjectival causative verbs in Modern English generate a simple syntactic structure with two obligatory syntactic valencies: the subject and the direct object. Conversely, they generate a complex semantic structure with the following obligatory semantic valencies: Agent, Cause, Patient, and Objective. By considering semantic features as basic, it is rational to posit that all verbs under consideration entail Agent or Cause as they perform the role of the causing event. Both the former and the latter are in complementary distribution and do not concurrently occur at the surface level. The obligatory semantic valencies Patient and Objective are embedded in one semantic construction and expressed by one syntactic valency, namely the direct object. Finally, and most importantly, it can be assumed that the aforementioned syntactic and semantic valencies are embedded in any causative construction with deadjectival causative verbs in Modern English.

\section{References:}

1. Bogdanova, S.Yu. (2000) Otadjektivnyje glagoly s poslelogami "up" $i$ "down". // Lingvističeskije paradigmy i lingvodidaktika. / Tezisy dokladov i soobshenij V megdynarodnoj konferencii. Irkutsk.

2. Comrie, N. and Polinsky, M. (1993) Causatives and Transitivity. Amsterdam: John Benjamins.

3. Dirven, R. (1995) The Construal of Cause: The Case of Cause Prepositions. // Language and the Cognitive Construal of the World. / Ed. by J.R. Taylor and R.E. MacLaury. New York: Mouton de Gruyter.

4. Dlugosh, A.M. (1980) Anglijskij analitičeskij kauzativ so slugebnym glagolom "to get”. / Dissertacija na soiskanije yčënoj stepeni kandidata filologičeskix nauk. Kiev. 
5. Goldberg, A. (1995) Constructions: A Construction Grammar Approach to Argument Structure. Chicago and London: The University of Chicago Press.

6. Nedjalkov, V.P. and Sil'nickij, G.G. (1969) Tipologija morfologičeskogo i leksičeskogo kauzativov. [Typology of morphological and lexical causatives]. // Tipologija Kauzativnyx Konstrukcyi: Morfologičeskij Kauzativ. / Ed. by A.A. Xolodovič. Leningrad: Nauka.

7. Nedyalkov, V.P. and Silnitsky, G.G. (1973) The Typology of Morphological and Lexical Causatives. // Trends in Soviet Theoretical Linguistics. / Ed. by F. Kiefer. Dordrecht: Reidel.

8. Shibatani, M. (Ed.) (1976) The Grammar of Causative Constructions: Syntax and Semantics 6. New York: Academic Press.

9. Song, J.J. (1996) Causatives and Causation: A Universal-Typological Perspective. London and New York: Longman.

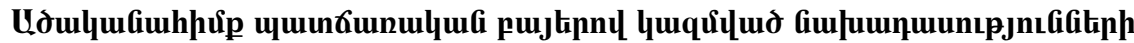

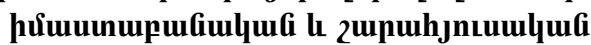 lunnıgludpfitinn duúufiuluuhg ufiq! tiptinıu}

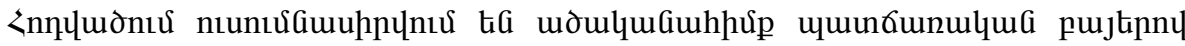

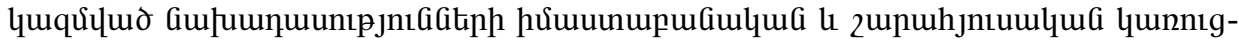

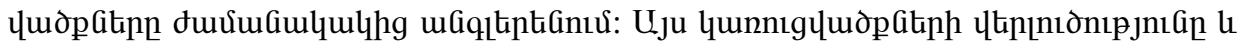
hupuptinulgnıpjnı

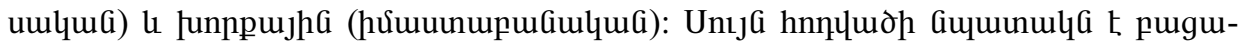

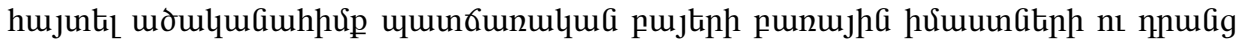

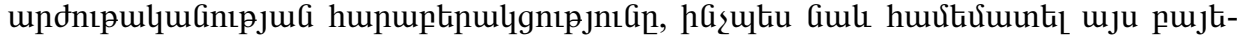

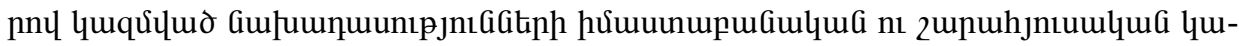
nnıgluдpGitin: 